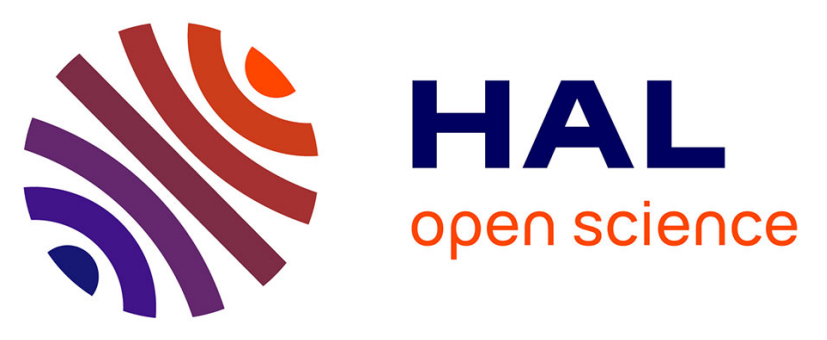

\title{
The palaeoecological value of Diporotheca rhizophila ascospores (Diporothecaceae, Ascomycota) found in Holocene sediments from Lake Nussbaumersee, Switzerland
}

Martina Hillbrand, Philippe Hadorn, Carole Cugny, Albin Hasenfratz, Didier Galop, Jean Nicolas Haas

\section{To cite this version:}

Martina Hillbrand, Philippe Hadorn, Carole Cugny, Albin Hasenfratz, Didier Galop, et al.. The palaeoecological value of Diporotheca rhizophila ascospores (Diporothecaceae, Ascomycota) found in Holocene sediments from Lake Nussbaumersee, Switzerland. Review of Palaeobotany and Palynology, 2012, 186 (62-68). hal-01207871

\section{HAL Id: hal-01207871 \\ https://hal.science/hal-01207871}

Submitted on 1 Oct 2015

HAL is a multi-disciplinary open access archive for the deposit and dissemination of scientific research documents, whether they are published or not. The documents may come from teaching and research institutions in France or abroad, or from public or private research centers.
L'archive ouverte pluridisciplinaire HAL, est destinée au dépôt et à la diffusion de documents scientifiques de niveau recherche, publiés ou non, émanant des établissements d'enseignement et de recherche français ou étrangers, des laboratoires publics ou privés. 
Research paper

\title{
The palaeoecological value of Diporotheca rhizophila ascospores (Diporothecaceae, Ascomycota) found in Holocene sediments from Lake Nussbaumersee, Switzerland
}

\author{
Martina Hillbrand ${ }^{\mathrm{a}, *}$, Philippe Hadorn ${ }^{\mathrm{b}}$, Carole Cugny ${ }^{\mathrm{c}}$, Albin Hasenfratz ${ }^{\mathrm{d}}$, \\ Didier Galop ${ }^{\text {c }}$, Jean Nicolas Haas ${ }^{\text {a }}$ \\ a University of Innsbruck, Unit of Plant Evolution and Diversity, Research Group Palynology and Archaeobotany, Sternwartestrasse 15, A-6020 Innsbruck, Austria \\ b 25 rue des Coteaux, $\mathrm{CH}-2016$ Cortaillod/NE, Switzerland \\ c Laboratoire Géode, Maison de la Recherche, Université Toulouse II - Le Mirail, 5 Allées Antonio Machado, F-31058 Toulouse cedex 9, France \\ ${ }^{\mathrm{d}}$ Archaeology Department of Canton Thurgau, Schlossmuehlestrasse 15a, CH-8510 Frauenfeld, Switzerland
}

\section{A R T I C L E I N F O}

\section{Article history:}

Received 10 February 2012

Received in revised form 26 June 2012

Accepted 27 June 2012

\section{Keywords:}

non-pollen palynomorphs

Diporotheca

Neolithic Period

anthropogenic impact

prehistorical erosion

Switzerland

\begin{abstract}
A B S T R A C T
Lake Nussbaumersee, a medium-sized lake SW of Lake Constance (Switzerland) and well known for its Neolithic and Bronze Age pile-dwelling settlements, provides invaluable insights into the possible interpretation of Diporotheca rhizophila ascospores (Diporothecaceae, Ascomycota) in palaeoecological studies. Calcareous gyttja sediments from a 7500 yrs old stratigraphy were analysed palynologically, resulting in statistical correlations of Diporotheca spores with pollen and non-pollen palynomorphs (NPPs). Positive correlation existed with arboreal taxa such as Corylus avellana and Acer, herb taxa such as Allium, and aquatic taxa such as Anabaena (Cyanobacteria) and Filinia eggs (Rotifera). Negative statistical correlation was shown between Diporotheca and the arboreal taxa Quercus and Betula, Poaceae and Cyperaceae, and the fern Pteridium aquilinum. These results suggest that ecological indicator values for the root parasite $D$. rhizophila may not only be closely related to the autecology of its common host Solanum, but that $D$. rhizophila may generally be an indicator of major soil disturbance and extensive soil erosion due to the impact of agricultural activities by prehistorical people, as well as due to livestock trampling of wetlands and lake shore ecosystems.
\end{abstract}

(C) 2012 Elsevier B.V. All rights reserved.

\section{Introduction}

Lake Nussbaumersee, situated in the region southwest of Lake Constance (Switzerland; Fig. 1), is well known for its Neolithic and Bronze Age pile dwellings (Hasenfratz and Schnyder, 1998). Lake sediments therefore allow palynological and palaeoecological research on how prehistorical societies and their livestock influenced their environment. During the last 25 years three lakeside settlements in and around Lake Nussbaumersee were excavated and dendrochronologically dated to the Neolithic and to the Bronze Age (Fig. 1). The Neolithic settlement "Inseli" from the Pfyner Culture is one of the longest lasting pile-dwelling settlements all over Central Europe for this time period and existed from 3840 BC to at least 3700 BC (Hasenfratz and Schnyder, 1998). Vegetation-historical aspects since the Late Glacial and the influence of prehistorical pile-dwelling societies on the surrounding flora and vegetation of Lake Nussbaumersee were the subject of the first palynological studies focussing on pollen, cryptogam spores and some selected non-pollen palynomorphs (Rösch, 1985; Haas and Hadorn, 1998).

\footnotetext{
* Corresponding author.

E-mail addresses: Martina.Hillbrand@uibk.ac.at (M. Hillbrand), phadorn@sunrise.ch (P. Hadorn), cugny@univ-tlse2.fr (C. Cugny), archaeologie@tg.ch (A. Hasenfratz), didier.galop@univ-tlse2.fr (D. Galop), Jean-Nicolas.Haas@uibk.ac.at (J.N. Haas).
}

Given the significant alterations on the upland flora during the Neolithic shown in the study by Haas and Hadorn (1998), major follow-up research was recently initiated on the prehistoric human impact on past littoral wetland and lake ecosystems of Lake Nussbaumersee using detailed analysis of locally produced non-pollen palynomorphs from the same sediment samples. Indeed, research on non-pollen palynomorphs (NPPs) has received increasing attention as they have proven to be highly useful in palaeoecological reconstructions (van Geel, 2003; Haas, 2010). However, NPP-analysis is still not a standard method in palaeoecological research, due to the dearth of identification keys, identification problems and often poorly known environmental indicator values. In addition, many of these microfossils are significantly smaller than most pollen and therefore more difficult to detect.

Ascospores of the fungus Diporotheca rhizophila (Diporothecaceae, cf. Lumbsch and Huhndorf, 2007 and Index Fungorum Partnership, 2012) are about the size of medium-sized pollen grains $(47-52 \times 17-25 \mu \mathrm{m}$; van Geel et al., 2003) and can therefore easily be counted during standard palynological analyses. These spores (often also named as NPP type HdV-143 in the palynological literature; Fig. 2) are very distinctive by their surface with dark brown anastomosing ribs and their two large pores and tapering ends, but they may have different shapes as mature and immature spores can be released from one perithecium (Gordon and Shaw, 1960). Such ascospores were first described from Holocene sediments by van der Wiel (1982) who placed them under the 


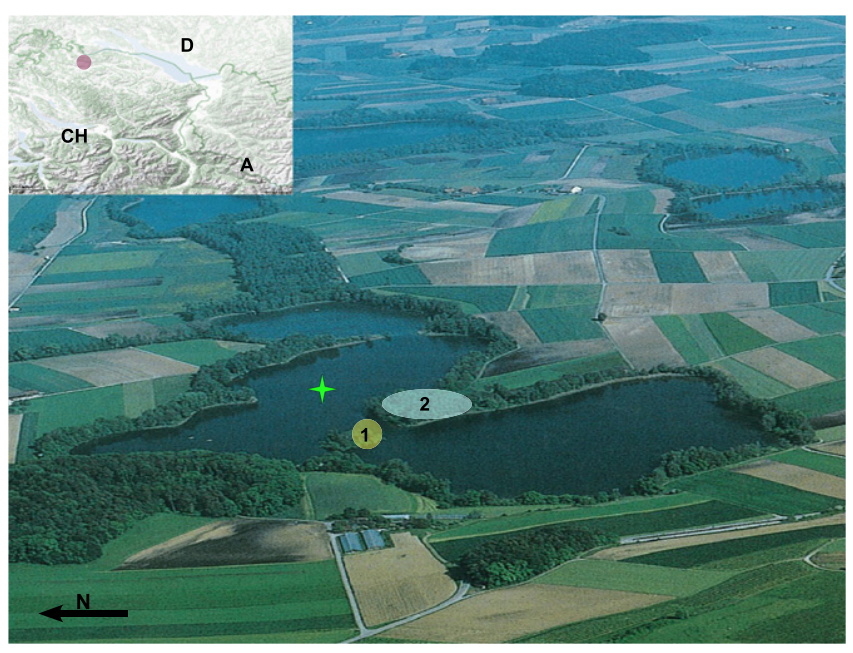

Fig. 1. The research area of Lake Nussbaumersee in NE Switzerland (inset map, upper left). The Neolithic pile dwelling settlement "Inseli" is shown with a yellow circle (1), the location of the Late Bronze Age settlement "Ürschhausen-Horn" is shown in blue (2). The coring point is indicated by a green star. (Abbreviations: CH: Switzerland, A: Austria, D: Germany.) Photo by P. Nagy, Winterthur.

unidentified fungal spore type 143. Then, van Geel et al. (1986) identified the type as Diporotheca sp. and van Geel and Aptroot (2006) recently recognised it as D. rhizophila C.C. Gordon and C.G. Shaw.

Diporotheca is widespread all over the world, as spores were not only found in palaeoecological studies of Eemian and Holocene sediments in Europe, but have also been described from lake sediments on the American and African continents (van Geel et al., 1986, 2011; Almeida-Lenero et al., 2005; Gelorini et al., 2011). The genus currently includes two species (Diporotheca litseae M.S. Patil and Diporotheca rhizophila C.C. Gordon and C.G. Shaw), whereby only D. rhizophila is known to occur on plants native to Europe.

Diporotheca rhizophila is known to be a parasite on the roots of Solanum species (nightshade family; Gordon and Shaw, 1960). In
Europe this fungus grows especially on roots of Solanum nigrum which mainly grows under wet meso- and eutrophic conditions in disturbed environments such as forest openings, alder carrs, reed belts, and as ruderals or on agricultural fields (Ellenberg and Leuschner, 2010). For this reason, findings of spores of $D$. rhizophila have often been seen as indicative for past and extant nutrient rich, eutrophic wetland conditions (e.g. Ramezani et al., 2008; Montoya et al., 2010; Wheeler et al., 2010), which were often interpreted to be the result of human influence. Although other host-parasite relationships are up to now not known for $D$. rhizophila from the mycological literature, some palynological studies argued for other possible hosts, such as the wetland fern Thelypteris palustris because of analogies in the past frequency of occurrences (van Geel et al., 1986; van Geel and Aptroot, 2006).

In this paper we present correlations between Holocene Diporotheca ascospores and pollen and other non-pollen palynomorphs in order to get a better understanding of their value as palaeoenvironmental indicators for Quaternary palynological studies.

\section{Materials and methods}

\subsection{Study site}

The valley of Seebachtal is located to the southwest of Lake Constance in the Swiss Canton of Thurgovia (Thurgau) and was formed during the Last Glacial period (Würm). Nowadays, the Seebachtal valley contains three lakes of which Lake Nussbaumersee is the westernmost (Fig. 1). Its lake level is at about $434 \mathrm{~m}$ a.s.l., and the lake surface area is approximately 27 ha, with a maximum water depth of about $8 \mathrm{~m}$. Lake Nussbaumersee is divided into three separate basins currently connected with each other, but which were separated during the Early Holocene due to isostatic rebound and climatic change (Hasenfratz and Schnyder, 1998). Today, remnants of a Magnocaricion (dominated by Carex elata) and of an Alno-Ulmion alder carr forest with Alnus glutinosa (alder), several Salix (willow) species and Frangula alnus (alder buckthorn) characterise the vegetation zones along the shores of the lake. The upland vegetation is dominated - apart from large agricultural fields - by Fagus

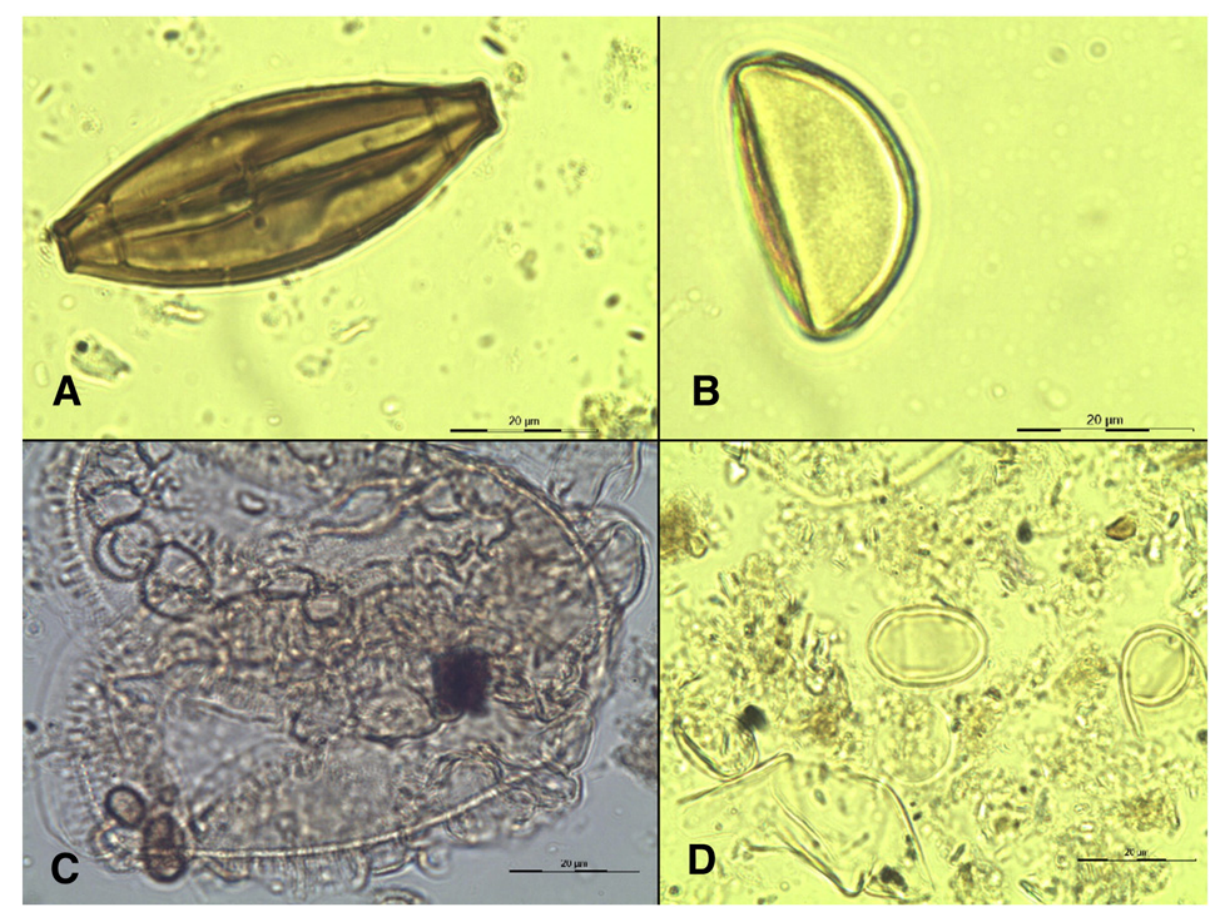

Fig. 2. Selected NPPs and pollen from the Holocene sediments of Lake Nussbaumersee (Switzerland). A: Diporotheca rhizophila, B: Allium sp., C: Filinia sp., D: Anabaena sp. (length of bar: $20 \mu \mathrm{m})$. 
sylvatica (beech) forests (Fig. 1), which exist on stony-clayey soils since beech immigration about 7000 years ago (Haas and Hadorn, 1998).

\subsection{Archaeological settings}

Thanks to intensive studies by archaeologists and palaeoecologists, the prehistory of the area of Lake Nussbaumersee is quite well known (Haas and Hadorn, 1998; Hasenfratz and Schnyder, 1998). Three main lakeside settlements (Fig. 1) below and just above today's water level were excavated and dendrochronologically dated to the Neolithic Period (3840 to at least 3700 BC; Pfyner Culture), the Late Early Bronze Age (1580-1538 BC) and to the Late Bronze Age (ca. 850-800 BC). The Neolithic pile-dwelling village (Nussbaumersee-"Inseli") was formerly lying on a land bridge between the north-western and south-eastern lake shores, and was inhabited for at least 140 years. In spite of the medium size of the village (with approximately 30 houses) a major forest opening was recognised by palynological means, while the much bigger Late Bronze Age lakeside village "Ürschhausen-Horn" (with more than 100 buildings) showed comparably little impact on the surrounding vegetation (Haas and Hadorn, 1998).

\subsection{Palynological settings}

A calcareous gyttja sediment core (NBS-1993; with a total length of $950 \mathrm{~cm}$ ) was taken in 1993 from the deepest point of Lake Nussbaumersee using a Livingstone type corer (Fig. 1; geographical coordinates: $47^{\circ} 36^{\prime} 52^{\prime \prime} \mathrm{N} / 8^{\circ} 49^{\prime} 20^{\prime \prime} \mathrm{E}$ ). Thereafter sediment sub-samples of $1 \mathrm{~cm}^{3}$ each were taken at four centimetre steps for palaeoecological analyses, whereby the uppermost $230 \mathrm{~cm}$ (representing the Medieval Period and the Modern Times) was not analysed. All sediment samples were prepared for palynological study following standard procedures (Moore et al., 1991), including sediment sieving through a $200 \mu \mathrm{m}$ mesh sieve (to separate microfossils from macrofossils) and by applying a 1-minute acetolysis, but no hydrofluoric acid (HF) treatment. Lycopodium spores were added to determine the concentration of microfossils (Stockmarr, 1971). Apart from pollen and cryptogam spores studied earlier (Haas and Hadorn, 1998), all non-pollen palynomorphs (NPPs) were counted from the same sample residues. Detailed NPP analysis was generally done at $8 \mathrm{~cm}$ steps, with exception of the Neolithic settlement phase, where samples were analysed at
$4 \mathrm{~cm}$ intervals. NPPs were identified and counted using a light microscope (at a magnification of $600 \times$ ). All NPP types were determined using mycological and palynological literature (Lundqvist, 1972; van Geel, 1972; Pals et al., 1980; van Geel et al., 1981, 1989, 1996, 2003; Barthelmes et al., 2006; van Geel and Aptroot, 2006), as well as the reference collection of the Hugo de Vries Laboratory (HdV, University of Amsterdam, The Netherlands).

Haas and Hadorn (1998) counted a minimum of 500 pollen grains per sample and calculated the percentage of each taxon in comparison to the defined $100 \%$-pollen sum (=total of arboreal and non-arboreal pollen, excluding pollen from aquatics, as well as fern and moss spores). For the quantification of NPPs presented in this study between 15 and 85 Lycopodium spores were counted depending on palynological concentrations, resulting in 140 to more than 1500 non-pollen palynomorphs per sample (average 576). In samples with very high numbers of certain types (i.e. Anabaena and Aphanizomenon) these types were only counted to a lower number of Lycopodium spores and then extrapolated. Using the Lycopodium counts in each sample and the defined pollen sum by Haas and Hadorn (1998), the NPP influx values and percentages in relation to the defined $100 \%$ pollen sum were calculated. The percentage values of selected taxa are presented using Tilia version 1.7.16 software (Grimm, 2011).

\subsection{Statistical analysis}

To test the correlation between Diporotheca spores and all pollen and other non-pollen palynomorphs taxa, a bivariate correlation test was performed on percentage values using SPSS 18 software (IBM, New York, NY, USA) calculating the Pearson coefficient in a two-sided correlation. Since the samples in the stratigraphy are not independent of each other, partial correlations controlling for several abundant variables (total tree pollen, diatoms, microscopic charcoal, total fungal spores) and showing no correlation with Diporotheca, were also calculated.

\subsection{Radiocarbon dates}

A first series of 12 AMS-radiocarbon dates was performed on terrestrial macrofossils in 1994-1997 at the ETH Zürich, Switzerland (Table 1; see also Haas and Hadorn, 1998) and recently, four additional

Table 1

List of ${ }^{14} \mathrm{C}$-dates performed on terrestrial plant macrofossils from the calcareous gyttja sediment core of Lake Nussbaumersee (Switzerland). Dates in italics were not used for the chronological interpolation (see Fig. 3). Calibration of radiocarbon dates was done using IntCal09 and OxCal v4.1.7 (Reimer et al., 2009; Bronk Ramsey, 2010). Most probable ages are given according to the Clam-model run on original ${ }^{14} \mathrm{C}$-dates (Blaauw, 2010). (Abbreviations: $\mathrm{BS}=$ bud scales, $\mathrm{C}=$ catkin parts, $\mathrm{L}=$ leaf parts indet, $\mathrm{S}=$ seeds, $\mathrm{SL}=$ substantia lignosa indet.)

\begin{tabular}{|c|c|c|c|c|c|c|}
\hline $\begin{array}{l}\text { Depth } \\
(\mathrm{cm})\end{array}$ & Sample no. & ${ }^{14} \mathrm{C}$ date & Delta ${ }^{13} \mathrm{C}$ & $\begin{array}{l}\text { Age calibrated } \\
(\text { mean } \pm 2 \sigma)\end{array}$ & $\begin{array}{l}\text { Most probable age } \\
\text { (Clam model) }\end{array}$ & Material dated \\
\hline $88-90$ & ETH-41472 (UZ-5920) & $75 \pm 40 \mathrm{BP}$ & $-61.1 \pm 1.1$ & AD $1809 \pm 127$ & AD 1821 & SL \\
\hline $246-248$ & ETH- 17753 & $1455 \pm 60 \mathrm{BP}$ & $-24.6 \pm 1.2$ & $A D 550 \pm 120$ & AD 585 & Fagus sylvatica BS \\
\hline $253.5-262.5$ & ETH-14265 & $2500 \pm 95 B P$ & $-2.7 \pm 1.2$ & $605 \pm 205 B C$ & & Alnus glutinosa S, SL \\
\hline $316.5-325.5$ & ETH-11845 & $2905 \pm 55 B P$ & $-28.7 \pm 1.1$ & $1095 \pm 175 B C$ & & $\begin{array}{l}\text { Alnus glutinosa S, Betula sect. alba S, } \\
\text { Betula pendula S, Fagus sylvatica BS }\end{array}$ \\
\hline $374-376$ & ETH-41473 (UZ-5921) & $2600 \pm 70 \mathrm{BP}$ & $-73.7 \pm 1.1$ & $714 \pm 201 \mathrm{BC}$ & $720 \mathrm{BC}$ & Alnus sp. C, BS indet. \\
\hline $424.5-430.5$ & ETH-14266 & $3385 \pm 75 B P$ & $-22.7 \pm 1.3$ & $1700 \pm 190 B C$ & & Alnus glutinosa S, Betula pubescens S, SL \\
\hline $446-448$ & ETH-41474 (UZ-5922) & $3115 \pm 55 \mathrm{BP}$ & $-78.6 \pm 1.1$ & $1362 \pm 140 \mathrm{BC}$ & 1379 ВС & Fagus sylvatica BS \\
\hline $472.5-475.5$ & ETH-14267 & $3900 \pm 80 \mathrm{BP}$ & $-19.8 \pm 1.2$ & $2355 \pm 225 B C$ & & Alnus glutinosa S, L \\
\hline $476-478$ & ETH-41475 (UZ-5923) & $3360 \pm 55 \mathrm{BP}$ & $-74.1 \pm 1.1$ & $1684 \pm 178 \mathrm{BC}$ & $1651 \mathrm{BC}$ & Alnus sp. C, L \\
\hline $559.5-562.5$ & ETH-11846 & $3970 \pm 50 \mathrm{BP}$ & $-29.7 \pm 1.1$ & $2455 \pm 165 \mathrm{BC}$ & 2482 BC & Alnus sp. C \\
\hline $610.5-613.5$ & ETH-11847 & $4405 \pm 60 \mathrm{BP}$ & $-30.6 \pm 1.2$ & $3120 \pm 220 \mathrm{BC}$ & $3081 \mathrm{BC}$ & Alnus sp. C \\
\hline $631.5-640.5$ & ETH-11848 & $4785 \pm 90 \mathrm{BP}$ & $-19.9 \pm 1.2$ & $3540 \pm 180 B C$ & & $\begin{array}{l}\text { Alnus sp. C, Alnus glutinosa S, } \\
\text { Tilia sp. BS, bark remains }\end{array}$ \\
\hline $692.5-704.5$ & ETH-11849 & $4830 \pm 65 \mathrm{BP}$ & $-20.8 \pm 0.9$ & $3570 \pm 200 \mathrm{BC}$ & $3604 \mathrm{BC}$ & $\begin{array}{l}\text { Alnus sp. C, Alnus glutinosa S, } \\
\text { Betula pubescens } \mathrm{S} \text {, } \\
\text { Betula sect. alba S }\end{array}$ \\
\hline $775.5-784.5$ & ETH-11850 & $5460 \pm 60 \mathrm{BP}$ & $-27.7 \pm 1.1$ & $4265 \pm 195 \mathrm{BC}$ & $4304 \mathrm{BC}$ & Alnus glutinosa S, Alnus sp. C, Tilia sp. BS \\
\hline $878.5-881.5$ & ETH-11851 & $6045 \pm 60 \mathrm{BP}$ & $-32.4 \pm 1.2$ & $4995 \pm 215 \mathrm{BC}$ & $4955 \mathrm{BC}$ & SL \\
\hline $943.5-949.5$ & ETH-11852 & $6665 \pm 65 \mathrm{BP}$ & $-29.7 \pm 1.1$ & $5595 \pm 115$ BC & 5586 BC & Alnus sp. C, Alnus glutinosa S, Tilia sp. BS \\
\hline
\end{tabular}




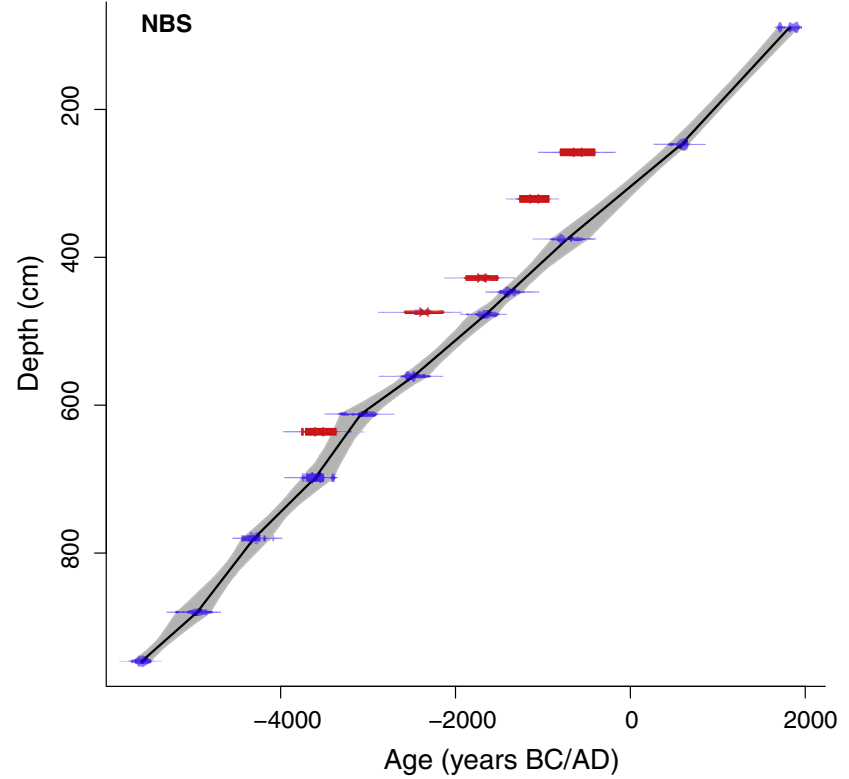

Fig. 3. Age-depth model for the sediments of Lake Nussbaumersee (Switzerland) using the Clam model (Blaauw, 2010). Radiocarbon dates not used for the chronological interpolation are crossed out.

AMS-radiocarbon dates were obtained from the same Institute after pre-treatment at the Geographical Institute of the University of Zürich (UZ; Table 1). Five ${ }^{14} \mathrm{C}$-dates were excluded for the linear chronological age interpolation as they were viewed as less reliable compared to the obtained relative ages of corresponding pollen data. The final agedepth model (Fig. 3) was created using Clam software (Blaauw, 2010). This age-depth model shows a near linear relation between age and depth in the part of the sediment core used for NPP analyses and was subsequently used for the interpretation of the palynological results using Tilia software (Grimm, 2011; Fig. 4). Given the age-depth model we therefore assume an almost unvarying sedimentation rate in the deepest, central part of the lake from ca. 5500 BC to AD 1800 (corresponding to $948-88 \mathrm{~cm}$ sediment depth; Fig. 3).

\section{Results}

\subsection{Palynology}

A diagram of selected pollen and NPP types from the Lake Nussbaumersee stratigraphy (NBS) is shown in Fig. 4. Pollen data showed a significant increase of non-arboreal (herb) pollen percentages between ca. 3900-3600 BC (740-700 cm depth) which must be attributed to Neolithic agricultural activities, especially in connection with the pile-dwellers from 3840 to 3700 BC (Haas and Hadorn, 1998; Hasenfratz and Schnyder, 1998). With the newly obtained NPP results, several lake water eutrophication phases can be detected. These are (inter alia) represented by peaks of Cyanobacteria (especially Aphanizomenon and Anabaena; Fig. 2), which are very probably a result of high nutrient input by the lakeside people (van Geel et al., 1994). Diporotheca rhizophila thereby peaked from about 3790 to 3560 BC (720-692 cm sediment depth) which corresponds well with the Neolithic pile-dwelling phase (Nussbaumersee-“Inseli"). Both after and before this period, Diporotheca is present in most samples in very low percentages, except for the lowermost parts of the sediment core, where percentages were higher.

\subsection{Statistical analysis}

Correlation tests (Table 2) resulted in significant positive correlations of percentages of Diporotheca spores with several pollen and non-pollen palynomorphs: Highly significant correlations were found with Anabaena (Cyanobacteria), which also shows a peak in the Neolithic Period as well as Filinia eggs (Rotifera). Highly significant correlations exist also with tree pollen of Corylus avellana (hazel) and the herbal taxon Allium. Significant positive correlations of Diporotheca is shown with Acer pollen (maple) and the hitherto unknown NPP type cf. HdV-182. On the other hand, Diporotheca rhizophila presence is negatively correlated with the arboreal taxa Quercus (oak) and Betula (birch), as well as with Poaceae, Cyperaceae, and Pteridium aquilinum (bracken). None of the other 260 pollen and NPP taxa from this study showed any significant correlation with Diporotheca. Partial correlations controlling for several variables (total tree pollen, diatoms, microscopic charcoal, total fungal spores) were calculated since samples in the stratigraphy are not independent of each other. The results differed very slightly from the correlations originally calculated, so only a selection is shown in Table 2.

\section{Discussion}

Diporotheca rhizophila is known as a mildly pathogenic fungus, parasitical on the surface of roots of several Solanum species (Mibey and Hawksworth, 1995). Our results leave room for two different interpretations, which may both be valid to a varying degree in different geographical and climatic settings.

\subsection{Host species}

The ascospore finds from the sediments of Lake Nussbaumersee showed no correlation with Solanum pollen, which is probably due to the fact that wild, insect pollinated Solanum species produce a relatively small amount of pollen which is weakly dispersed. This is a common feature, as several palaeoecological studies with Diporotheca rhizophila spores in their palynological preparations did not find any (or very few) pollen of Solanum species (e.g. van Geel et al., 2003). The plant macrofossil analysis of the Lake Nussbaumersee sediment core did not provide any evidence of Solanum seeds or leaves either (Hillbrand, data not shown). However, the palaeoethnobotanical study of the cultural layers from the Neolithic pile-dwelling settlement Nussbaumersee-"Inseli" (3840-3700 BC) revealed that these layers contained several seeds of Solanum dulcamara and Solanum nigrum (Hillbrand, unpublished data), which confirms the growth of Solanum species in the vicinities of Lake Nussbaumersee. So, we assume that the peak in Diporotheca may be related to the regular presence of Solanaceae on agricultural fields, forest clearings or reed belts during the Neolithic. The positive correlation of $D$. rhizophila spores with Allium pollen might point to the near-lake presence of a fen wood or of beech (Fagus sylvatica) forests, both the typical ecosystems where e.g. Allium ursinum must have been dominant during Neolithic times, as also known from other prehistorical settings in Switzerland (Hadorn, 1994; Haas and Hadorn, 1998). This would also be the habitat where S. dulcamara occurs (Ellenberg and Leuschner, 2010) which would favour the growth of Diporotheca. This could explain why several palynological studies show a visible relation between Alnus or Salix and Diporotheca (e.g. Bos et al., 2005; Gelorini et al., 2006; Menozzi et al., 2010; Deforce, 2011). Prager et al. (2006) studied modern non-pollen palynomorphs from three different alder carrs and found that $D$. rhizophila lies inside a group of NPPs representative of wet conditions with mosses. So, an alder carr may have been present around Lake Nussbaumersee during periods of wet climate before and after the Neolithic settlement period as indicated by high values of Alnus (Fig. 4). In this context, and although there is no correlation between Alnus pollen and Diporotheca spores in the sediment core from Lake Nussbaumersee, the results of the plant macrofossil analysis from the same core showed a significant correlation between D. rhizophila spores and Alnus macrofossils (seeds and catkin-scales $>250 \mu \mathrm{m}$; see Fig. 4). 


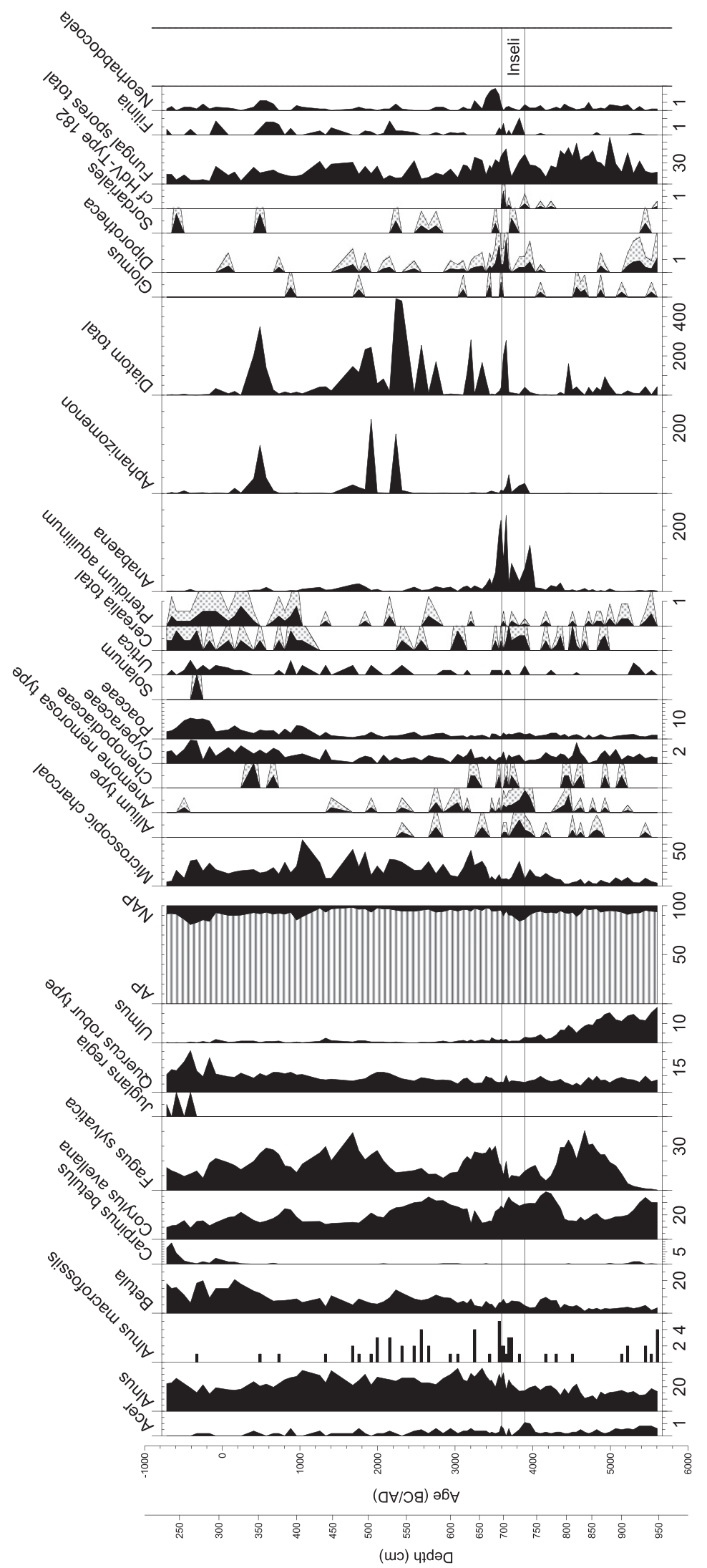


Table 2

Statistical correlations (Pearson coefficient) between Diporotheca rhizophila ascospore finds and selected pollen and non-pollen palynomorphs taxa (percentages) and partial correlations corrected for indicated factors from the Holocene sediments of Lake Nussbaumersee (Switzerland).

\begin{tabular}{|c|c|c|c|c|c|}
\hline \multirow[t]{2}{*}{ Taxon } & \multirow[t]{2}{*}{ Significance } & \multirow[t]{2}{*}{ Correlation coefficient } & \multicolumn{3}{|c|}{ Partial correlation (significance) corrected for: } \\
\hline & & & Diatoms & Charcoal & Fungal spores indet \\
\hline \multicolumn{6}{|c|}{ Positive bivariate correlation } \\
\hline Anabaena & $0.000^{* *}$ & 0.669 & $0.667(0.000)$ & $0.669(0.000)$ & $0.670(0.000)$ \\
\hline Corylus & $0.009^{* *}$ & 0.263 & $0.259(0.010)$ & $0.264(0.009)$ & $0.269(0.008)$ \\
\hline Allium & $0.006^{* *}$ & 0.274 & $0.280(0.005)$ & $0.273(0.007)$ & $0.274(0.007)$ \\
\hline Filinia & $0.010^{* *}$ & 0.260 & $0.260(0.010)$ & $0.267(0.008)$ & $0.265(0.009)$ \\
\hline cf Type 182 & $0.015^{*}$ & 0.246 & $0.247(0.015)$ & $0.245(0.016)$ & $0.247(0.015)$ \\
\hline Acer & $0.047^{*}$ & 0.201 & $0.200(0.049)$ & $0.201(0.049)$ & $0.200(0.049)$ \\
\hline \multicolumn{6}{|c|}{ Negative bivariate correlation } \\
\hline Betula & $0.029^{*}$ & -0.221 & $-0.217(0.032)$ & $-0.220(0.030)$ & $-0.240(0.018)$ \\
\hline Quercus & $0.030^{*}$ & -0.219 & $-0.225(0.027)$ & $-0.218(0.032)$ & $-0.229(0.024)$ \\
\hline Pteridium & $0.032^{*}$ & -0.217 & $-0.229(0.024)$ & $-0.218(0.032)$ & $-0.216(0.034)$ \\
\hline Cyperaceae & $0.038^{*}$ & -0.210 & $-0.214(0.035)$ & $-0.209(0.040)$ & $-0.210(0.039)$ \\
\hline Poaceae & $0.044^{*}$ & -0.204 & $-0.218(0.032)$ & $-0.215(0.034)$ & $-0.206(0.043)$ \\
\hline
\end{tabular}

$\mathrm{N}=98$.

** Highly significant $(<0.01)$.

* Significant $(<0.05)$.

On the other hand, in a study of modern NPPs performed in the Pyrenees Mountains (Cugny, 2011), Diporotheca rhizophila spores were found in moss samples from small, grazed wetlands, while they were absent in the mosses taken from adjacent terrestrial ecosystems (beech forests, clearings, heathland, grasslands). The only two sites where Solanum species were present in the local vegetation of this study were terrestrial sites where no $D$. rhizophila ascospores were found. Therefore we support the hypothesis proposed by van Geel et al. (1986) and van Geel and Aptroot (2006) that other host plants may exist for D. rhizophila, such as the wetland fern Thelypteris palustris. Thelypteris palustris also grows mainly in alder carr and similar habitats which leads us to suggest that even if Solanum is not found in pollen studies, the presence of Diporotheca is likely to indicate the existence of habitats where Solanum species and - as our results and comparisons with other studies indicate - mainly Solanum dulcamara grow (i.e. wet and nutrient rich conditions).

\subsection{Erosion}

The growth of Diporotheca on roots in the soil means that Diporotheca spores are probably mainly dispersed by soil erosion. In the Pyrenees Diporotheca rhizophila spores were most abundant in a wet zone highly trampled by livestock (Cugny, 2011). This suggests that soil disturbance, and subsequent extensive soil erosion might be decisive for the presence of $D$. rhizophila ascospores in wetland soils, and subsequently also in palynological samples from lake sediments. Taking these considerations into account, the high input of Diporotheca spores in Lake Nussbaumersee was probably due to the increased soil erosion and agricultural run-off, resulting in the highly significant positive correlation of Diporotheca with Anabaena and Filinia due to related rising lake water nutrient levels (eutrophication). This hypothesis is supported by the findings of Glomus which show no statistical correlation with Diporotheca but usually occur together with Diporotheca spores (Fig. 4). In addition, soil disturbance is indicated by the highly significant correlation between Diporotheca ascospores and pollen from shrubs and trees such as Corylus avellana and Acer, quickly and intensively growing within disturbed forest ecosystems and on abandoned agricultural fields. The negative statistical correlation of $D$. rhizophila with grasses (Cyperaceae and Poaceae), trees (Quercus and Betula) and ferns (Pteridium aquilinum) probably indicates that closed forests have prevented the erosion of soil in periods with low human impact and, subsequently, the spreading of ascospores of $D$. rhizophila towards the lake. This may therefore have led to an under-representation of Diporotheca in the palynolo-gical data set during times of low anthropogenic pressure.

In summary, high values of Diporotheca rhizophila ascospores may indicate (1) distinctive, local prehistorical soil disturbance and extensive erosive input of soil matter towards Lake Nussbaumersee and (2) the existence of wet and eutrophic habitats where hosts of Diporotheca grow. So, spores of this fungal genus may generally be a valuable disturbance indicator for prehistorical human and livestock activities in the wetlands and forests adjacent to lakes, as well as for disturbances and erosion processes within semi-opened landscapes (agricultural field systems) favouring the dispersal of spores of Diporotheca. On the other hand our study - once again - was not able to show any significant correlations between Solanum species and Diporotheca, which leads us to support the theory that the fungus may have other possible hosts (van Geel et al., 1986). These hosts, however, would probably have a similar autecology as Solanum species, but remain to be detected by future mycological research. Nevertheless, ascospores of $D$. rhizophila should be seen as an indicator for meso- to eutrophic and often wet habitats, combined with major soil disturbance and extensive erosion processes, which in turn may help to enlighten the structure and composition of prehistorical landscape features and past environments.

\section{Acknowledgments}

Many thanks go to the Archaeology Department of the Canton Thurgau (Switzerland) for financial resources to MH for this study, as well as for funding all radiocarbon dates. Many thanks also go to the Office for International Relations at the University of Innsbruck (Austria) for financial support to MH for her scientific work at the University of Amsterdam (The Netherlands) in 2010, where part of the research presented here was conducted at the Hugo de Vries Laboratory of the Institute for Biodiversity and Ecosystem Dynamics. Therefore, many special thanks go to the huge support received from Bas van Geel to $\mathrm{MH}$, as well as to the support given by the staff at the Hugo de Vries Laboratory, especially to Annemarie Philip for her help in preparing pollen slides. Bas van Geel was thereby a steadily and invaluable help in identifying known and unknown NPPs and in interpreting the subsequent results. We therefore would like to thank Bas van Geel for his generous work - without which this research would not have been possible - and to dedicate this publication to him in order to congratulate him on his never-ending enthusiasm on non-pollen palynomorphs. Finally we would like to thank two anonymous reviewers for their valuable remarks which improved this paper considerably. 


\section{References}

Almeida-Lenero, L., Hooghiemstra, H., Cleef, A.M., van Geel, B., 2005. Holocene climatic and environmental change from pollen records of lakes Zempoala and Quila, central Mexican highlands. Review of Palaeobotany and Palynology 136, 63-92.

Barthelmes, A., Prager, A., Joosten, H., 2006. Palaeoecological analysis of Alnus wood peats with special attention to non-pollen palynomorphs. Review of Palaeobotany and Palynology 141, 33-51.

Blaauw, M., 2010. Methods and code for "classical" age-modelling of radiocarbon sequences. Quaternary Geochronology 5, 512-518.

Bos, J.A.A., van Geel, B., Groenewoudt, B.J., Lauwerier, R.C.G.M., 2005. Early Holocene environmental change, the presence and disappearance of early Mesolithic habitation near Zutphen (The Netherlands). Vegetation History and Archaeobotany 15 , 27-43.

Bronk Ramsey, C., 2010. OxCal program V4.1. http://c14.arch.ox.ac.uk/embed.php? File $=$ oxcal.html 2010(06.02.2012).

Cugny, C., 2011. Apports des microfossiles non-polliniques à l'histoire du pastoralisme sur le versant nord pyrénéen. Entre référentiels actuels et reconstitution du passé. $\mathrm{PhD}$ thesis. University of Toulouse-II Le Mirail, France.

Deforce, K., 2011. Middle and Late Holocene vegetation and landscape evolution of the Scheldt estuary. A palynological study of a peat deposit from Doel (N-Belgium) Geologica Belgica 14 (3-4), 277-288.

Ellenberg, H., Leuschner, C., 2010. Vegetation Mitteleuropas mit den Alpen - in ökologischer, dynamischer und historischer Sicht. Verlag Eugen Ulmer, Stuttgart. $1334 \mathrm{pp}$.

Gelorini, V., Verleyen, E., Verbruggen, C., Meersschaert, L., 2006. Paleo-ecologisch onderzoek van een Holocene sequentie uit het Deurganckdok te Doel (Wase Scheldepolders, Noord-België). Belgeo 3, 243-264.

Gelorini, V., Verbeken, A., van Geel, B., Cocquyt, C., Verschuren, D., 2011. Modern nonpollen palynomorphs from East African lake sediments. Review of Palaeobotany and Palynology 164, 143-173.

Gordon, C.C., Shaw, C.G., 1960. A new genus of the Meliolaceae on the roots of Solanum species. Mycologia 52 (2), 327-333.

Grimm, E.C., 2011. Tilia version 1.7.16 [software]. Illinois State Museum, Springfield, Illinois, USA.

Haas, J.N. (Ed.), 2010. Fresh insights into the palaeoecological and palaeoclimatologica value of Quaternary non-pollen palynomorphs. Veget. Hist. Archaeobot. 19 (5-6).

Haas, J.N., Hadorn, P., 1998. Die Vegetations- und Kulturlandschaftsgeschichte des Seebachtals von der Mittelsteinzeit bis zum Frühmittelalter anhand von Pollenanalysen. In: Hasenfratz, A., Schnyder, M. (Eds.), Das Seebachtal - Eine archäologische und paläoökologische Bestandesaufnahme: Forschungen im Seebachtal 1. Archäologie im Thurgau, 4, pp. 221-255

Hadorn, P., 1994. Saint-Blaise/Bains des Dames 1. Palynologie d'un site néolithique et histoire de la végétation des derniers 16000 ans. Archéologie Neuchâteloise 18 $1-121$

Hasenfratz, A., Schnyder, M., 1998. Neolithische und bronzezeitliche Siedlungsreste am Nussbaumersee. In: Hasenfratz, A., Schnyder, M. (Eds.), Das Seebachtal - Eine archäologische und paläoökologische Bestandesaufnahme: Forschungen im Seebachtal 1. Archäologie im Thurgau, 4, pp. 53-184.

Index Fungorum Partnership, 2012. Index Fungorum. http://www.indexfungorum.org 2012(06.02.2012).

Lumbsch, H.T., Huhndorf, S. (Eds.), 2007. Outline of Ascomycota. Myconet 13, 1-58.

Lundqvist, N., 1972. Nordic Sordariaceae s.lat. Symb. Bot. Ups. 20 (1), 20 (1), pp. 1-374.

Menozzi, B.I., Zotti, M., Montanari, C., 2010. A non-pollen palynomorphs contribution to the local environmental history in the Ligurian Apennines: a preliminary study. Vegetation History and Archaeobotany 19, 503-512.

Mibey, R.K., Hawksworth, D.L., 1995. Diporothecaceae, a new family of ascomycetes, and the term "hyphopodium". Systema Ascomycetum 14, 25-31.

Montoya, E., Rull, V., van Geel, B., 2010. Non-pollen palynomorphs from surface sediments along an altitudinal transect of the Venezuelan Andes. Palaeogeography, Palaeoclimatology, Palaeoecology 297, 169-183.
Moore, P.D., Webb, J.A., Collins, M.E., 1991. Pollen Analysis. Blackwell Scientific Publications, Oxford. 216 pp.

Pals, J.P., van Geel, B., Delfos, A., 1980. Paleoecological studies in the Klokkeweel bog near Hoogkarspel (Noord-Holland). Review of Palaeobotany and Palynology 30 371-418.

Prager, A., Barthelmes, A., Theuerkauf, M., Joosten, H., 2006. Non-pollen palynomorphs from modern Alder carrs and their potential for interpreting microfossil data from peat. Review of Palaeobotany and Palynology 141, 7-31.

Ramezani, E., Mohadjer, M.R.M., Knapp, H.-D., Ahmadi, H., Joosten, H., 2008. The lateHolocene vegetation history of the Central Caspian (Hyrcanian) forests of northern Iran. The Holocene 18, 307-321.

Reimer, P.J., Baillie, M.G.L., Bard, E., Bayliss, A., Beck, J.W., Blackwell, P.G., Bronk Ramsey, C., Buck, C.E., Burr, G.S., Edwards, R.L., Friedrich, M., Grootes, P.M., Guilderson, T.P., Hajdas, L, Heaton, T.J., Hogg, A.G., Hughen, K.A., Kaiser, K.F., Kromer, B., McCormac, F.G Manning, S.W., Reimer, R.W., Richards, D.A., Southon, J.R., Talamo, S., Turney, C.S.M., van der Plicht, J., Weyhenmeyer, C.E., 2009. IntCal09 and Marine09 radiocarbon age calibration curves, 0-50,000 years cal BP. Radiocarbon 51 (4), 1111-1150.

Rösch, M., 1985. Nussbaumer Seen - Spät- und postglaziale Umweltveränderungen einer Seengruppe im östlichen Schweizer Mittelland. In: Lang, G. (Ed.), Swiss Lake and Mire Environments during the Last 15000 Years. Cramer, Vaduz, pp. 337-379.

Stockmarr, J., 1971. Tablets with spores used in absolute pollen analysis. Pollen et Spores 13 614-621.

van der Wiel, A.M., 1982. A palaeoecological study of a section from the foot of the Hazendonk (Zuid-Holland, the Netherlands), based on the analysis of pollen, spores and macroscopic plant remains. Review of Palaeobotany and Palynology $38,35-90$.

van Geel, B., 1972. Palynology of a section from the raised bog 'Wietmatscher Moor', with special reference to fungal remains. Acta Botanica Neerlandica 21 (3) 261-284.

van Geel, B., 2003. Non-pollen palynomorphs. In: Smol, J.B., Birks, H.J.B., Last, W.M. (Eds.), Tracking Environmental Change Using Lake Sediments. Terrestrial, Algal, and Siliceous Indicators, Volume 3. Kluwer Academic Publishers, Dordrecht, The Netherlands, pp. 99-119.

van Geel, B., Aptroot, A., 2006. Fossil ascomycetes in Quaternary deposits. Nova Hegwigia 82, 313-329.

van Geel, B., Bohncke, S.J.P., Dee, H., 1981. A Palaeoecological study of an upper Late Glacial and Holocene sequence from "De Borchert", The Netherlands. Review of Palaeobotany and Palynology 31, 367-448.

van Geel, B., Klink, A.G., Pals, J.P., Wiegers, J., 1986. An Upper Eemian lake deposit from Twente, eastern Netherlands. Review of Palaeobotany and Palynology 47, 31-61.

van Geel, B., Coope, G.R., Van der Hammen, T., 1989. Palaeoecology and stratigraphy of the Lateglacial type section at Usselo (the Netherlands). Review of Palaeobotany and Palynology 60, 25-129.

van Geel, B., Mur, L.R., Ralska-Jasiewiczowa, M., Goslar, T., 1994. Fossil akinetes of Aphanizomenon and Anabaena as indicators of medieval phosphate-eutrophication of Lake Gosciaz (Central Poland). Review of Palaeobotany and Palynology 83, 97-105.

van Geel, B., Odgaard, B.V., Ralska-Jasiewiczowa, M., 1996. Cyanobacteria as indicators of phosphate-eutrophication of lakes and pools in the past. PACT 50, 399-415.

van Geel, B., Buurman, J., Brinkkemper, O., Schelvis, J., Aptroot, A., van Reenen, G. Hakbijl, T., 2003. Environmental reconstruction of a Roman Period Settlement site in Uitgeest (The Netherlands), with special reference to coprophilous fungi. Journal of Archaeological Science 30, 873-883.

van Geel, B., Gelorini, V., Lyaruu, A., Aptroot, A., Rucina, S., Marchant, R., Damsté, J.S.S. Verschuren, D., 2011. Diversity and ecology of tropical African fungal spores from a 25000-year palaeoenvironmental record in southeastern Kenya. Review of Palaeobotany and Palynology 164 (3-4), 174-190.

Wheeler, J., Swindles, G.T., Gearey, B.R., 2010. Finding Bosworth Battlefield: a multiproxy palaeoenvironmental investigation of lowland sediments from Dadlington, Leicestershire, England. Journal of Archaeological Science 37, 1579-1589. 